\title{
Phenomoenology Study on Financial Performance and Management Accountability of Special Autonomy Funds Allocated for Education at the Province of Papua, Indonesia
}

\author{
JohnAgustinus \\ School of Economics Jayapura Port Numbay, Jayapura, Indonesia
}

\begin{abstract}
Abstact: Special autonomy in education is regarded as a great blessing for the Papua people. They have high expectation that Special autonomy funds allocated for education will elevate their living quality including school provisions and living standard. The population of the research, however, perceived that such wishes and expectations did not match with the reality. It is assumed that there had been mismanagement of the funds. The study is aimed at reviewing special autonomy financial performance and its management accountability. The study is performed through a qualitative approach with a phenomenological strategy - a study which is conducted at particular setting in a real live (natural setting) to investigate and understand phenomena. The data were collected from government employee, NGO officers, the target population, and other resources by observation, in-depth interviews, and library reviews. The results show that local government officials lack of capacity in handling the funds and there had been poor budget management as indicated from four management functions - planning, executing, reporting, and monitoring of educational funds - which were not implemented appropriately. A concept as a set of law and regulation that shapes Special Autonomy fund management of Papua Province is needed. Therefore, an integrated mechanism of building compliance and control system of educational funds management is necessary to reach the Value for Money (effectiveness, efficiency, and economics) of education budget. It is recommended that knowledge building and understanding on the financial performance as mandated in Special Autonomy Article will strengthen the achievement of the target as stated in the vision, mission, and objectives which supported by a construct culture of transparency, frankness, accuracy, and accountability.
\end{abstract}

Abstrak: Otonomi khusus dalam pendidikan dianggap sebagai berkah besar bagi rakyat Papua. Mereka
memiliki harapan tinggi bahwa dana otonomi khusus dialokasikan untuk pendidikan akan meningkatkan
kualitas hidup mereka termasuk ketentuan sekolah dan standar hidup. Penelitian populasi, bagaimanapun,
dirasakan bahwa keinginan tersebut dan harapan tidak sesuai dengan kenyataan. Hal ini diasumsikan bahwa
telah terjadi salah urus dana. Penelitian ini bertujuan untuk mengkaji kinerja otonomi khusus keuangan dan
akuntabilitas manajemen. Penelitian ini dilakukan melalui pendekatan kualitatif dengan strategi-studi
fenomenologis yang dilakukan pada setting tertentu dalam (pengaturan alam) hidup nyata untuk menyelidiki
dan memahami fenomena. Data dikumpulkan dari karyawan pemerintah, petugas LSM, populasi sasaran,

Corresponding authors. E-mail: johnlecture69@yahoo.com; www.johnagustinus.com

ISSN: 1141-1128

http://www.gamaijb.mmugm.ac.id/ 
dan sumber daya lainnya dengan cara observasi, wawancara mendalam, dan ulasan perpustakaan. Hasil menunjukkan bahwa pejabat pemerintah daerah kekurangan kapasitas dalam menangani dana dan sudah ada pengelolaan anggaran yang buruk seperti yang ditunjukkan dari empat fungsi manajemen perencanaan, pelaksanaan, pelaporan, dan pemantauan pendidikan dana - yang tidak dilaksanakan dengan tepat. Sebuah konsep sebagai seperangkat hukum dan regulasi yang membentuk otonomi pengelolaan dana khusus Provinsi Papua diperlukan. Oleh karena itu, mekanisme terpadu kepatuhan bangunan dan sistem pengendalian manajemen dana pendidikan yang diperlukan untuk mencapai value for money (efektivitas, efisiensi, dan ekonomi) dari anggaran pendidikan. Disarankan agar membangun pengetahuan dan pemahaman terhadap kinerja keuangan sebagaimana diamanatkan dalam pasal otonomi khusus akan memperkuat pencapaian target sebagaimana tercantum dalam visi, misi, dan tujuan yang didukung oleh budaya membangun transparansi, keterbukaan, akurasi, dan akuntabilitas .

Keywords: accountability; finance; special autonomy 


\section{Introduction}

The province's special autonomy status is granted to Papua local government to manage their own areas with little intervention from central government. Local officials have the authority with greater responsibility to govern and regulate the use of natural resources in Papua for the prosperity of the people of Papua including decentralized authority to manage the socio-cultural and economic potential of the Papua people by empowering special community groups, tribe leaders, spiritual leaders, and the women representatives.

Based on Constitution Law No. 21/ 2001 on Special Autonomy for Papua province, there are four fundamental principles that given to the Local Papua officers:

1. To regulate the authority between central government and local government of Papua as well as to implement and conduct it with some particularities,

2. To legitimate and respect on native Papua's basic rights as well as their strategic and fundamental empowerments,

3. To establish good public governance that is characterized by:

a. Higher participation of the people in planning, implementation, and control of government governance as well as the implementation of development that involves cultural/ethnic, religious, and women representatives.

b. Development implementation is directed optimally to fulfill the basic needs of native Papua in particular and Papua people in general.

c. Transparent and accountable government governance and development implementation for the society.
4. To delegate the authority, task with firm and clear responsibility among the legislative, executive, and judicative personals and Papua Community Forum which represents the native Papua who granted special authority.

Those principles are meant to achieve fairness, equality in law supremacy, respect on human rights, acceleration of economics development, and enhancement on social welfare and prosperity of Papua people, in attaining equality and balance with other provinces in Indonesia.

The implementation of Special Autonomy is hampered by the incomplete implementation guidance of the Law No.21/2001 on Special Autonomy for Papua. To implement the special autonomy, it needs a set of provincial regulation and special regional regulations. Until now, however, there have been some rules only on special regional regulation, while some other fundamental provincial rules have not yet been decided. As the results, there is no technical regulation on how to manage special authority at the province level or at regency or at city and town. In general, it happens because of slow process at the parliament and lack of coordination among provincial officers, provincial House of Representatives, and Community of Papua People (MRP). In the implementation level many rules and regulations were officially formulated by local house of representative but were not approved by the Community of Papua People (MRP) yet.

The special autonomy funds provide significant contribution for Papua province, regencies, cities and towns. Under the special autonomy, the central government has poured around Rp. 28 trillion into Papua since 2001. Within the period of 2004-2008, central government in Jakarta had contributed 
21.6 percent to the total revenue of the total local government's budget. For the provincial government alone, central government had distributed 42 percent of the total revenue. For regency/city government, during the same period, special autonomy fund had been contributed 12 percent of their total revenue.

The word accountability in this study is meant as the responsibility to generate a trustworthy audit through authority distribution on the local/regional government to prevent centralization of authority and to create peer check and balance system. Moeller (2009), Anderson and Narus (1990), Child and Faulkner (1998), Das and Teng (1998), Zaheer and Venkatraman (1995) proved empirically that there is direct relationship between accountability and participation to the financial performance. The decision makers such as manager, director, and stockholder are trusted by their network or business partner because of trusted financial performance and it enables them to enhance their financial performance, particularly in achieving good return. Furthermore, the manager, director, and business owner that are able to arrange partnership with their network are also able to maintain the financial performance to the positive direction.

Moeller (2009); Anderson and Darus (1990); Child and Faulkner (1998); Das and Teng (1998); Zaheer and Vankatraman (1995) all tried to identify the role of the trust and participation on financial performance. Moeller (2009) himself did not concentrate on the consequence of the main value of trust on financial performance but he put the emphasis on the value of trust which is related to the accountability variable. This research,therefore, fills the research gap of Moeller (2009) by adding accountability variable. It is based on Pekman's (1998),
Penrose's (1959), and Barney's (1991) research mentioning that public accountability has a long term effect on financial performance. This is based on the statement of Wernerfelf (1984); Teece 1998); D'Aveni (1995); as well as Das and Teng (2000) who all mention that the trust is inseparable from the accountability built to achieve positive objective of the financial performance. Based on the Financial Audit Agency (BPK) findings in 2008, the allocation of special autonomy fund for health service reached 10.96 percent; while for education sector it was only 6.2 percent. The allocation on both sectors were still below the standard as mandated in the constitution Law No.21/2001 which mentions that it should be 15 percent and 30 percent respectively for health service and education.

The background that causes problems on financial performance of Papua Province was postulated during a seminar entitled "Financial Transparency and Accountability at Papua Province" which was held by the Institution of Papua People Empowerment.

Referring to the law and regulation that set the amount of education budget allocation in APBD, as previously mentioned, the education budget of Papua province in 2010 was only 6.11 percent of the total APBD or it was just 11.99 percent from the special autonomy fund. It violated the 1945 Constitution, Special Autonomy Law No. 20/2003, government regulation No.48/2008, and local government regulation No.5/2006. It means that Papua's APBD in 2010, which defined 4.77 percent allocation for education, did not have binding legal force (that happened as well on the Papua's APBD in 20062009). Whereas, if it refers to the 1945 constitution, Law No. 20/2003, and government regulation No. 48/2008 which define minimum 20 percent budget allocation for edu- 
cation from total APBD, then the education budget of Papua in 2010 would have reached Rp. 1,024.91 billion for its minimum amount or equals to the amount of Rp 1.02 trillion. If it refers to Local government Law No.5/ 2006 which defines minimum 30 percent from total special autonomy fund so the education budget allocation of Papua's APBD in 2009 should be at least Rp. 782.94 billion.

\section{Research Focus}

Regional autonomy, particularly special autonomy of Papua Province, is the central government's commitment in order to reach equal development in Papua compared to other provinces, enhance Papua people welfare, as well as the right and pride of Papua people. Fund transfer policy of the central government to Papua Province, both equality and special autonomy funds have quite huge portion as compared to the average among the other provinces in Indonesia. Therefore, the main task of government as the biggest public organization is to create society welfare since welfare is a multi-complex concept. Government as the special autonomy fund manager is demanded to manage the finance with accountable and transparent principles. Education becomes the focal priority and gets huge fund to develop education in Papua Province. The problem is that during ten years implementation of special autonomy in Papua Province, the education condition is still low so that the guarantee of right and obligation of each citizen to obtain and join education are not yet sufficient, such as:

1. Low equality of education chance for inter-region, for different income distribution, and among gender.
2. Low quality and relevance of education since the curriculum is not related to the needs on the job vacancy availability, low quantity and quality of teacher, as well as limited facilities and infrastructure in education,

3. Weak education managerial establishment both for formal and private-based educations.

Financial performance basically is a system of arrangement and management of regional budget which is oriented to the achievement or performance results. The performance must reflect public service efficiency and effectiveness; it means that it is should be oriented to public interests. The basic principles to manage special autonomy fund are transparency, accountability, and Value of Money.

\section{Research Problems}

There is a huge special autonomy fund given by central government for the educational sector but it is not able to enhance the quality of education at Papua Province. It is even at lowest level. The problems examined in this research, therefore, are:

1. How are the performance and the accountability of special autonomy fund in education sector of Papua Province in term of its effectiveness in the improvement of education quality?

2. How can the society get the benefit of special autonomy fund for education sector?

3. What are the plan, implementation, report, and audit of special autonomy fund management in education sector? 


\section{Theoretical Framework}

\section{Financial Performance}

Regional/local development is inseparable from the respective officers that manage it. Each region has distinctive procedures in managing its development that made different performance. Performance appraisal is done based on the periodical review or evaluation of the activities; it is part of the respective officers' job, and the standard of the performance had been previously determined. Through financial performance, alone, the society will be able to evaluate the performance of government's officers. The performance appraisal can be measured from the financial analysis as it much depends on the different aspects of the activities that sponsored by the financial section. One of the functions of financial report is to provide information related to financial performance.

Another measurement can be done from the Accounting information which is very useful to access the officers' performance accountability. Both accounting information and non-accounting information may also be used to evaluate the head of the office or the whole performance of an organization. Sedarmayanti (2004:175-176), defines that the performance is the job outcome that can be achieved by an individual or a group of people in an organization, based on the authority and responsibility to achieve the organization's objective in legal way, not violating the law, and considering moral and ethic. Hayadi and Kristiani (2007:103), also define that the performance is a description of the level of activity or program implementation as the effort to achieve the objective, vision, and mission of an organization.

\section{Accountability}

According to Halim (2008) accountability is the attitude and behavior of decision maker in public, private, and civil society sectors who is responsible for the job he/she has conducted to the public and stakeholders. Actually, there are three reasons why regional financial management evaluation is needed. First, the delegation of authority and task to provincial government affected the recent practice of regional financial management which is proven to be inefficient in supporting good governance attainment. Then, the most important thing is that the new paradigm of "delegation of authority to regional government" in term of regional financial management must be directed to enhance higher social welfare. Finally, the emphasis is not only on the proportion of budget allocation but also on the range of benefits and the frequency of society's participation.

\section{Methodology}

The research is conducted through a qualitative approach with a phenomenological strategy - a study which is conducted at particular setting in a real live (natural setting) to investigate and understand phenomena; what had happened, why does it happen, and how does it happen. In other word, the research is based on the "going exploring" concept that involves in-depth and case oriented study on several cases or single case (Weber 1960). Qualitative research aims to make a fact to be understandable and, if possible it is based on its research model, produce new hypothesis. The research is performed by gathering information of the respective parties, particularly the regional government officers and the society that receive 
and get benefits from the special autonomy fund. To support the study, the information from the decision makers from Papua House of Representatives Members, and from NGO members in Papua that are competent to provide information is also collected.

\section{Data Collecting}

The data were collected through interview, in-depth interview, field observation, questionnaires, and library reviews. From the interview, then, common theme of the problems was identified. Among the themes are as follows:

1. The amount of education budget allocation can be seen from "the sum of regional government revenue and expenses" (APBD) and special autonomy fund;

2. The compliance of provincial government on the applicable law and regulation become the foundation to allocate and manage education budget;
3. The alignments of provincial government and regional house of representative as the political decision makers in the process of arrangement and appointment of $A P B D$ and special autonomy fund to finance the educational sector;

4. Provincial government had made the priority programs in education sector and the amount of supporting fund was taken from APBD;

5. Abuse and inefficiency indications in the budget utilization had been indicated.

Between 2001 and 2010, the Supreme Audit Agency (BPK) found indications that Rp 4.12 trillion of the $\mathrm{Rp} 19.12$ trillion in special autonomy funds for Papua and West Papua had been misused or embezzled. Within one year (2005-2006) the BPK found some indications of abuse in utilizing special autonomy fund Rp. 27.51 billion in 2005 for, and Rp.77.56 billion in 2006. Particularly for education sector's fund that was managed by

Table 1. Development of Special Autonomy Funds from 2002- 2010

\begin{tabular}{ccc}
\hline Year & Special Autonomy Fund (IDR) & Growth (\%) \\
\hline 2002 & $1,382,300,000,000$ & - \\
2003 & $1,527,011,000,000$ & 10.5 \\
2004 & $1,642,620,000,000$ & 7.6 \\
2005 & $1,775,310,000,000$ & 8.1 \\
2006 & $2,913,300,000,000$ & 64.1 \\
2007 & $3,295,630,000,000$ & 13.1 \\
2008 & $3,590,120,000,000$ & 8.9 \\
2009 & $2,609,790,000,000$ & -27.3 \\
2010 & $2,694,650,000,000$ & 3.3 \\
\hline
\end{tabular}

Source: BPK Report and Province of Papua Report 2010 
Education Department of Papua Province in 2005-2007, BPK found total abuse that caused loss of regional finance was Rp. 4.81 billion. The abuse occurred in the form of non-accountable expenditure (no attached valid payment receipts), inefficiency in goods and service procurement, and physical project implementation which does not match with the contract appointment. Regarding this phenomena, the ICS and FITRA Jakarta analysis team have not been able to obtain new information about the way how this problem is going to be solved.

\section{The Benefit of Special Autonomy}

The researcher identifies the benefits given to the Papua people by receiving special autonomy funds as well as the funds' influence on the public life. The results of the interview reveal that special autonomy budget neither improve educational level of the people nor enhance their life situation as depicted below:

\section{Informant $A 1$}

"...Special Autonomy is not yet able to solve education problem for Papua people since there is no prove on the distinct improvement to a better direction: (1) the alignment to native Papua to the inland area is still very small, (2) the number and quality of elementary and high school teachers are still limited, particularly for natural science subject. It makes teachers do extra role by teaching different subjects. Teacher's prosperity is still inadequate so that some of them have other additional job as motorcycle taxi driver in the evening to earn their life. This brings them to fatigue and spiritless in taking their responsibility as their function and task..."

\section{Informant $A 2$}

"Resistance of the society occurs related to the implementation of Special Autonomy since the implementation on the certain prioritized sectors is not quite obvious for its development. It does not make apparent improvement on education, health, economics of people, and some basic infrastructures. It has been 9 years of the Special Autonomy implementation; yet there is no distinct outcome that causes doubt from the people that education, health, economics of people, and infrastructures get enhanced."

\section{Data Analysis and Propositions}

The researcher identifies some rules and regulations about accountability in Papua Special Autonomy. Among the rules and law products are as follow:

1. Constitutional Law No 21 year 2001, Article 67 point 1. In running a proper, clean, authoritative, transparent and responsible government administration, legal supervision, political supervision and social supervision shall be exercised

2. Local government Law No 5 year 2006, Article 69 point 1. Local government functionally conducts auditing on Education establishment. Article 70 point 1 Education board conducts auditing on the plan and the implementation of education program.

3. Special Autonomy Law No 1 year 2007, Article 21 point. It is managed based on transparent, accountable, responsible principles that is free from corruption, collu- 
sion, and nepotism. Chapter 26 article 2 the audit covers planning, implementation, and responsibility in financial matters. Chapter 27 article 1 Provincial government, Papua House of Representatives (DPRP), and the society monitor the utilization of the income as the consequence of Special Autonomy implementation.

From those regulations above, the themes of accountability compliance of the government are derived. The government should provide responsibility or report and explain the performance of special autonomy fund management act to the party that holds the authority and right to evaluate their performance annually. They should report the accountability of the fund. The accountability in this respect is translated as the responsibility or answer and describes the performance and act during the process of planning, implementing, and controlling..." (BPK 2002)
Based on the financial management study, accountability and benefit of special autonomy, the researcher derives some premises that are presented on the research model on Figure 1. We can see from the model that Papua gets special autonomy fund for 30 percent from the Papua Province's Regional Budget Revenue and Expenses. It supposes, as the huge amount of fund that available for education sector by having so that education will have quality enhancement. Since there is a discrepancy in education sector at Papua Province and no quality enhancement occurs on the exact sector, but the financial performance for education management in Papua Province should have four strength indicators to improve the education sector as mentioned on Special Autonomy Law No 21 year 2001, Minster of State Decree No 13 year 2006, Local government Law No 5 year 2006 and Law of Specific Autonomy No 1 year 2005. Thus, if those four

Figure 1. Research Model

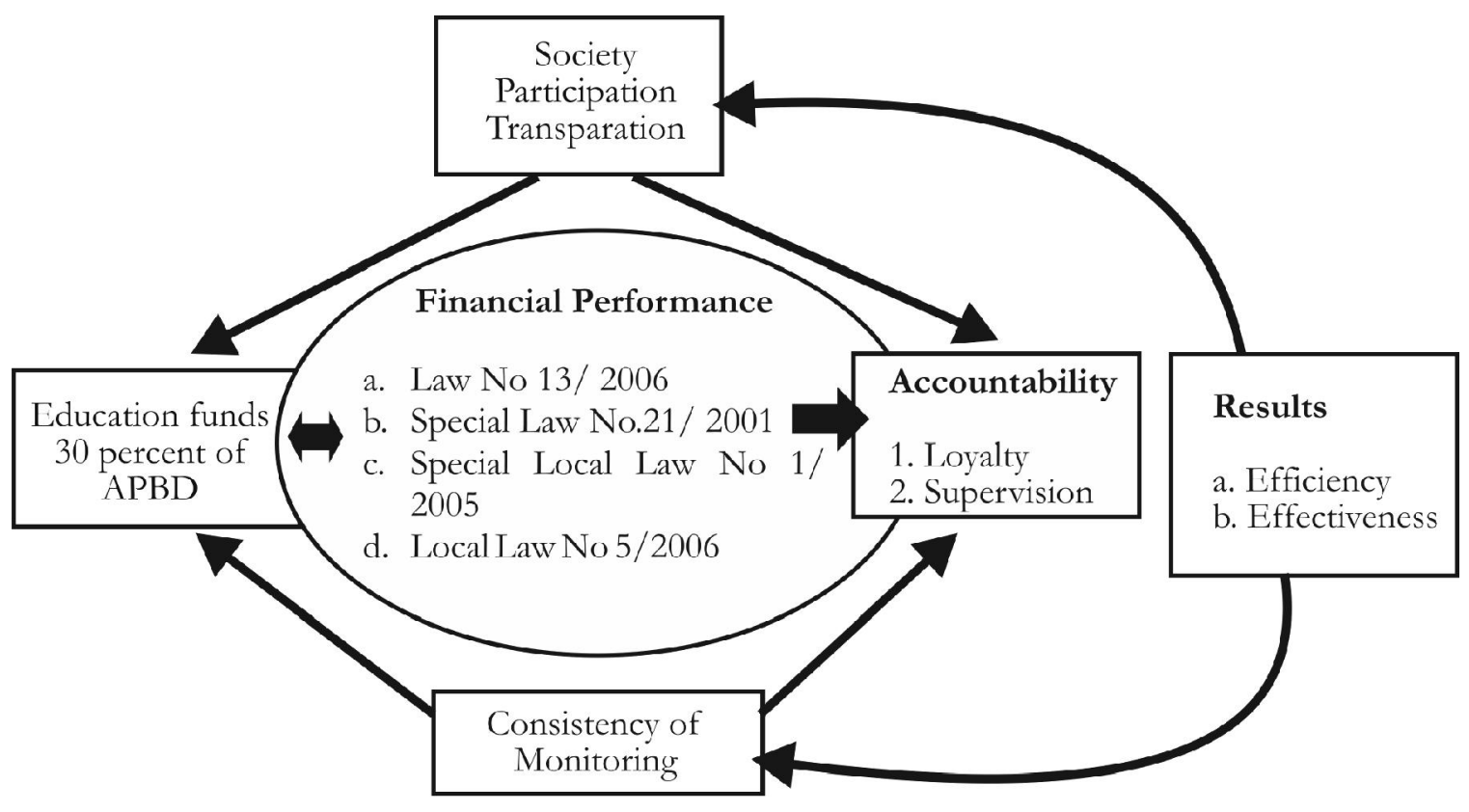


indicators of management are implemented in compliant with the principle, then the education sector of Papua Province should have been better. Besides, it needs tight audit and control from the Financial Audit Institution (BPK) as well as from public on the implementation of the autonomy on education sector. By implementing the tight and consistent audit and control each year, it will reduce the authority and mechanism abuse in managing special autonomy fund in education sector.

Based on the mapping in the minor proposition (Table 2), some major proposition can be formulated as follow:

1. Special Autonomy Law, government regulation, and compliance have defined financial performance of special Autonomy fund management.

Table 2. Minor Proposition

\section{Minor Proposition}

Its Relationship with Special Autonomy Fund Management
Special autonomy regulation and the set government regulation is the financial performance to manage special autonomy fund

The implementation of special autonmy regulation in Papua province provides authority for regional government to enhance education quality in Papua province

The special autonomy fund management should bring huge contribution to the society

Huge fund management and people's worry on the fund management because the basic reference of the society to judge the government related to its financial accountability

Accountability that is expected by Papua people defines the succesfulness in managing the special autonomy fund

Knowledge and understanding of geoverment officers on the meaning of special autonomy fund and how to the run UU Otonomi Khusus define the development successfulness Regional government accountability in managing special autonomy fund defines the compliance to enhance education quality

Failure to improve education quality will provide accountability to regional government and provide reference to improve special autonomy fund management compliance

The compliance to run a set of Special Autonomy Law accountability and fund management related to education quality and benefits for the society
Special Policy $\rightarrow$ Enhancement $\rightarrow$ Special Autonomy Law $\rightarrow$ Fund Management $\rightarrow$

Knowledge insight and worry of the society $\rightarrow$ successfulness and education quality $\rightarrow$ accountability

Compliance, fund management, effectiveness and efficiency, as well asomy fund, the benefit received by society $\rightarrow$ the ammount of special autonomy fund, education quality, audit $\rightarrow$ financial performance $\longrightarrow$ accountability 
2. The compliance, control, and responsibility on the special autonomy fund determine the accountability of special autonomy fund management.

3. Knowledge related to the education and experience are regarded as the foundation to manage the funds effectively and efficiently and then it will provide benefit to the people of Papua Province.

\section{Discussion}

The different meaning of financial performance and financial achievement in this research result on the finding of an inefficiency and ineffectiveness phenomenon of special autonomy' financial performance; it is also found the different accountability of special autonomy fund management. It is illustrated in the Figure 2.
Based on the Figure 2, it can be seen that there have been inefficiency and ineffectiveness of special autonomy fund management; They answers of the research questions that financial performance and accountability of special autonomy fund management in education sector in Papua Province that has not yet able to enhance education quality. The society also did not get the benefits of special autonomy fund in education sector. From the obtained themes and reduction step, one of the weaknesses that occur is on the compliance and control. Control is an integral part among the other stages in arranging and reporting APBD. Theoretically, audit is needed on each stage, not only on evaluation stage (Mardiasmo 2001). The control conducted by house of representative members is started during the process of APBD arrangement, legalization, implementation,

Figure 2.Illustration on the Inefficiency and Ineffectiveness of Special Autonomy Fund Management

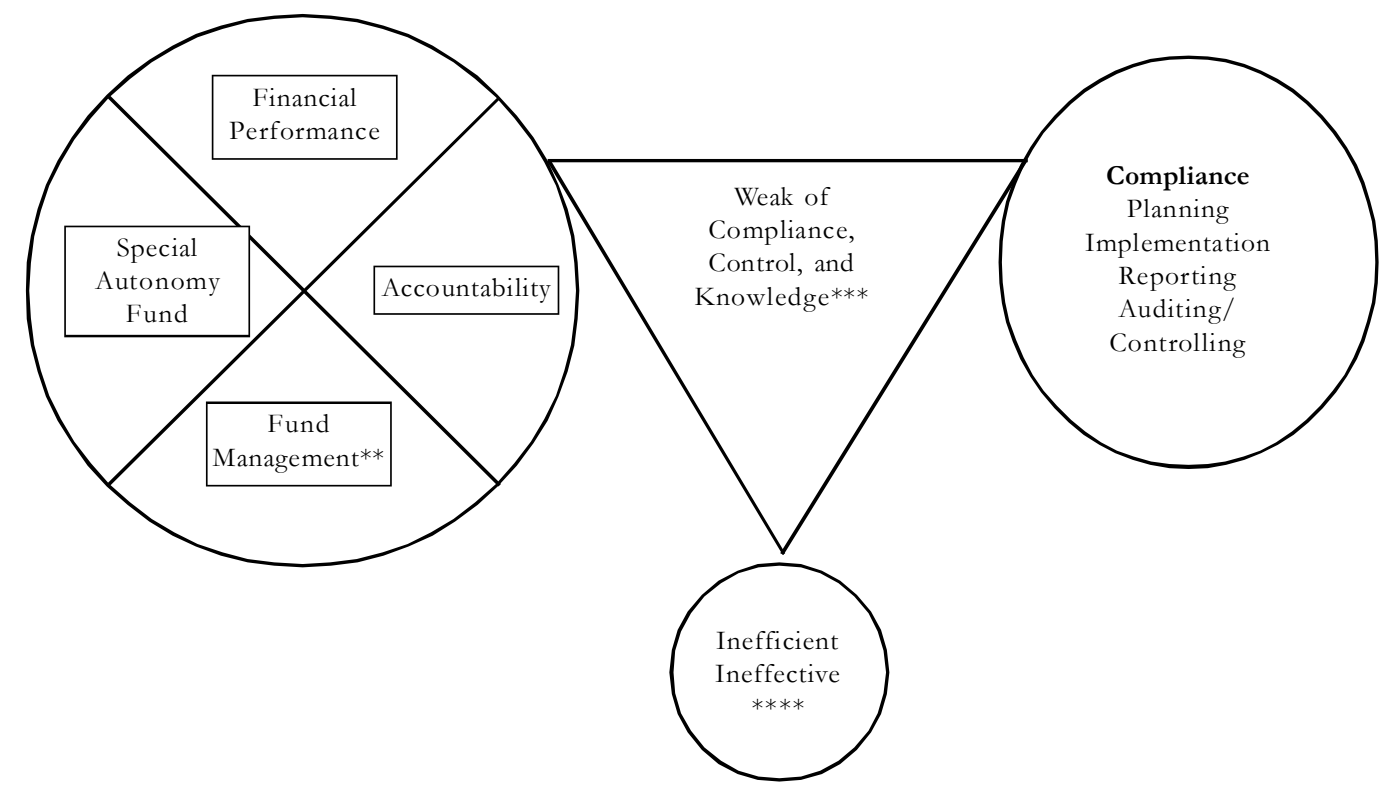

Source: Processed based on several references for this dissertation: *) Program of UU Otonomi Khusus, Perdasi No 6 2006; **) Accountability Report of Papua Province's Governor in 2010;***) Informants; **** BPK RI Audit Report in 2008, 2009 and 2011 
and accountability process. Alamsyah (1997) mentioned that the aim of APBD audit is (1) to control that the arranged budget that is implemented, (2) ensure that the implementation of APBD is relevant with the defined budget, and (3) ensure that APBD implementation is accountable

Since the regional autonomy has been implemented in Indonesia, several laws and regulations have been produced. Among the regulations are government Law, president decree, ministry decree, etc. All of them are made to ensure that the autonomy implementation can be well-established.

Kadmasasmita (2007: 9) and Mardiasmo (2007: 29) explain in detail that to better implement the concept of Value for Money, the National financial arrangement reformation requires $3 \mathrm{E}$ concept (economics, efficient, and effective). Therefore, in this reformation, the government is asked to always implement the $3 \mathrm{E}$ concept as seeking for fund and utilizing the fund. It encourages the government to put its effort to consider each cent/rupiah as they obtain and utilize the money. The attention goes to the relationship between input-output-outcome.

Special autonomy regulation and other set of regulations give the guidance of regional financial management of Papua Province as stated in Mulyadi (2005), Sucipto (2007), Jumingan (2006), and Sutrisno (2009). As there is additional fund for special autonomy, the financial management must refer to and comply with the law and regulation (Mulyadi 1997) and Halim (2008). It is expected that by implementing financial management based on the law and regulation, the effectiveness and efficiency of the program will be achieved.

Figure 3. Financial Performance and Accountability Model

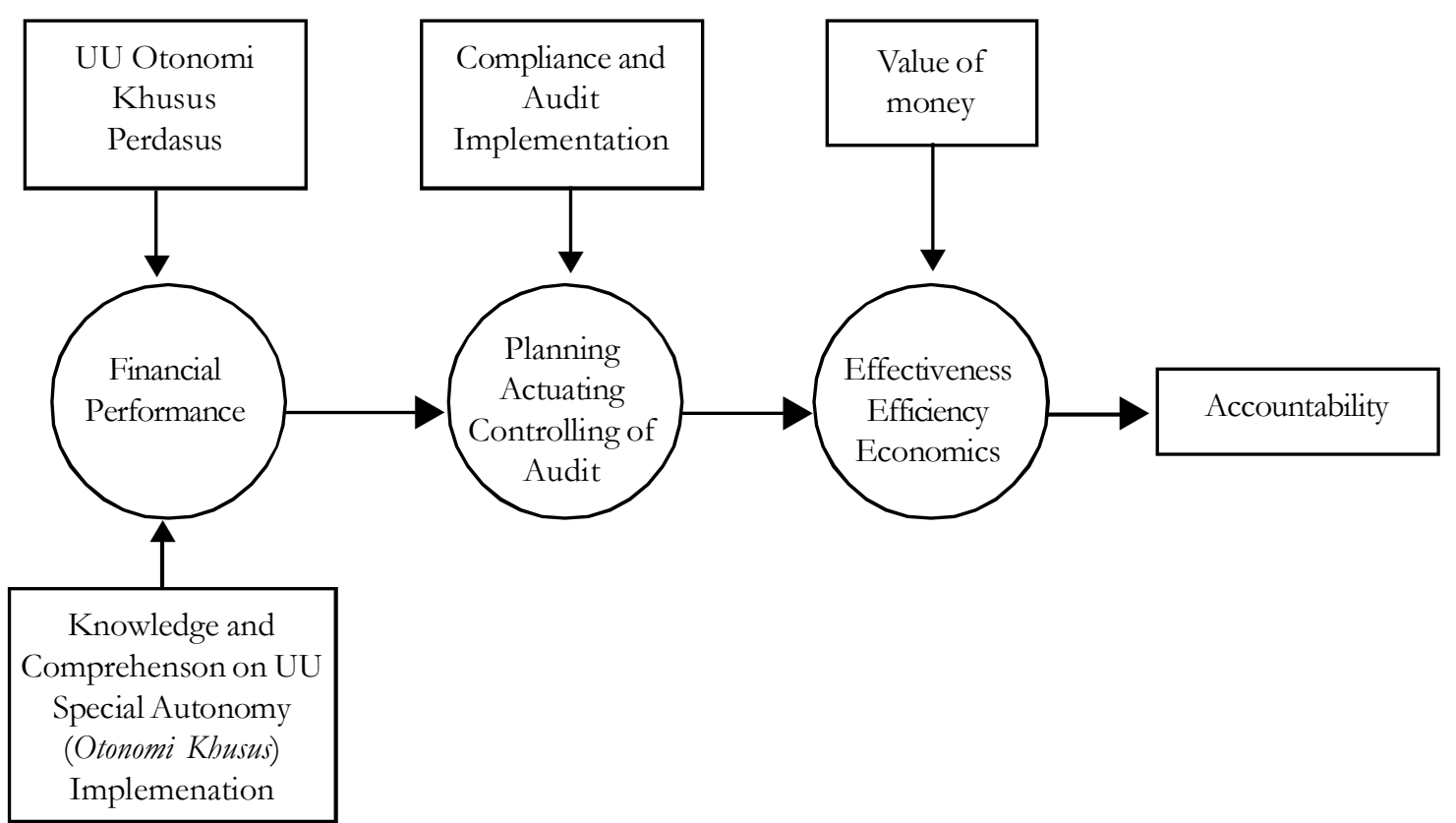

Source: Processed based on the several references of this dissertation; the main source are BPKP (2007:3), BPKRI (Financial Audit Agency of Indonesia Republic), and Informants 
Special autonomy fund given to Papua has affirmative action which means that this fund must be utilized to support the acceleration and enhancement program for Papuan as they have been left behind the other provinces (Sumule 2002). Understanding on the meaning of affirmative action must be possessed by the financial management officers; understanding the affirmative action is much needed since the management of special autonomy fund is different from ordinary regional autonomy financial management so that it demands particular financial management mechanism based on the strategic budgeting plan or based on the special autonomy mandate (for education and health services).

Knowledge and comprehension do really affect the performance; it is supported by the Supoyo's research (2006:154) which explains that knowledge influences performance. Thus, financial performance as well as efficiency and effectiveness attainment must be supported by law and regulation. The implementation of program must be based on the priority. The special autonomy fund utilization report must be correspond with the provided fund and the auditor should be functioned on the special autonomy fund management as mandated by law and regulation. From the audit results, the compliance on the principles of law and regulation of Papua Province's financial management will be revealed.

From the tight audit and control and mechanism compliance on the financial management based on the special autonomy regulation, it is expected to achieve maximum effectiveness and efficiency; therefore, special autonomy financial management officers should be responsible to answer and report the financial performance to the institution which has the right to ask for explanations and accountability report. To achieve maxi- mum financial performance, the special autonomy financial performance standards should be implemented and become organizational culture in financial management to achieve financial accountability (Supoyo 2006).

\section{Conclusion}

This research provides some findings that are not yet revealed by former and it delivers new concept of thought; those findings are:

1. (a) Financial performance is the achievement level in regional finance consisting of the region's revenue and expenditure by using the pre-determined financial system through some policy or regulation during one budgeting period. A set of law and regulation in special autonomy financial management shapes the mechanism of special autonomy financial management.

(b) The special autonomy fund management which is oriented to performance demonstrates performance accountability. Performance accountability is the manifestation of Papua provincial government's obligation to be accountable for the achievement or failure in the implementation of special autonomy fund management to attain the periodical goal and objective that are measured some performance indicators. Papua province is able to be responsible for the given special autonomy fund and able to provide explanations on the result and achievement as mandated in the law and regulation of special autonomy.

2. Individual's decision as an organization member to get involved in particular sys- 
tem and have greater role to achieve performance which is affected by his/her perception about reality that he/she comprehended. Special Autonomy fund management officers are individuals that have role to achieve the performance. Therefore, knowledge and insight that special autonomy is an affirmative action that absolutely needed to make the people more involved and have greater role to achieve the objective.

3. One of the main functions of financial management is compliance function. Implementing special autonomy fund management in compliant to the applicable law and regulation will create effective and efficient financial performance. Compliance function should be also implemented in financial management model including financial planning (budget), program implementation, financial report, as well as strict control to make the outcome of the financial management model from the plan to report stages is compliant to the applicable law and regulation. It makes special autonomy fund to bring high benefit to the society. Particularly in education sector, as the priority sector mandated in the Special Autonomy Law, the fund allocation of special autonomy should be managed to achieve better quality enhancement of the education sector.

\section{Research Limitation}

During interview and discussion, informants and discussion participants often provided information and statement related to political issues as the dominant answers. Political issue indeed defines the financial management of Papua Province; therefore, political issue in this research is reduced and processed as the supporting references of this research.

Some limitations of this research are as follows:

1. The researcher sometime gets some dispositions to meet other informants who are competent in Special Autonomy financial management theme.

2. The researcher finds difficulty to find the Papua government's annual accountability report,

3. The researcher has the obstacle to get guidance book to manage special autonomy fund and other references related to the topic

This phenomena create some themes for further research on the behavior of financial management officers. Regional financial management is oriented to performance demands for decentralization; by decentralization of regional financial management, it will be able to enhance the managerial role of the regional financial management officers.

\section{Suggestion}

Accountability implementation requires strong commitment of the governor and all staffs in the related institutions. They should assure the utilization of resources which is consistent with the applicable law and regulation. It should confirm the goal objective achievement level as well as the obtained result and benefit/advantage. It must be truthful, objective, transparent, and accurate. It should also present the achievement/failure to attain the determined goal and objective.

Thus, in implementing the financial performance and accountability for Papua Province, it should consider some principles as follow: 
1. There should be strong commitment of the governor and all staffs of the related institution in the implementation of management and the implementation of special autonomy fund's mission to be accountable;

2. It must build a system that is able to assure the utilization of resources which is consistent with the applicable law and regulation.

3. Must be able to show the achievement level of determined goal and objective

4. Must be truthful, objective, transparent, and innovative.

\section{References}

Anderson, J.C., and J. A. Narus. 1990. A model of distributor firm and manufacturer working partnerships. Journal of Marketing 4 (1): 42-58.

Barney. 1991. Knowledge and Accountability: Outside's Directors' Contribution in the Corporate Value Chain. Centre for Innovation, Research and Competence in the Learning Economy (CIRCLE) Lund University P.O. Box 117, Sölvegatan 16, S-221 00 Lund, SWEDEN http://www.circle.lu.se/publications ISSN 1654-3149

BPK R. I. 2008. Laporan Hasil Pemeriksaan (audited) Atas Pengelolaan dan Pertanggungjawaban Dana Otonomi Khusus Tabun Anggaran 2008 Pada Provinsi Papua.

BPK R. I. 2011. Laporan Hasil Pemeriksaan Atas Pengelolaan dan Pertanggungjawaban Dana Otonomi Khusus Tahun Anggaran 2002-2010 Pada Provinsi Papua dan Papua Barat.

Child, J., and Faulkner. 1998. Strategies of Cooperation: Managing Alliances, Networks and Joint Ventures. Oxford: Oxford University Press.

Das, T. K., and Teng. 2002. The dynamics of alliance conditions in the alliance development process. Journal of Management Studies 39 (5): 725-46.

Das, S., P. K. Sen, and Sengupta. 2003. Strategic alliances: A valuable way to manage intellectual capital. Journal of Intellectual Capital 4 (1): 10-19.

Das, T. K., and Teng. 2000. Instabilities of strategic alliances: An internal tensions perspective. Journal of Management Studies Organization Science 11 (1): 77-101.

D'Aveni. 1995. Coping with hypercompetition: Utilizing the new 7s's framework. Journal Academy of Management Executive Vol. ? (3): 45-60.

Halim, A. 2008. Manajemen Kenangan Daerah, Pengelolaan Kenangan Daerah (p. 6). Yogyakarta, Indonesia: Penerbit Unit Penerbit dan Percetakan STIM YKPN.

Hayadi.F., and Kristiani. 2007. Analisis kinerja bidan Puskesmas dalam pelayanan antenatal di Bengkulu Selatan. KMPK, WPS 11 (April). Yogyakarta

ICS (Jumpa Pers ). 2009. Hasil Analisis APBD Provinsi Papua Tabun 2009. Jayapura, Indonesia.

Jumingan. 2009. Analysis Financial Reports. Jakarta, Indonesia: Bumi Aksara .

Moeller, K. 2009. Intangible and financial performance: Causes and effects. Journal of Intellectual Capital 10 (2): 224-245. Emerald Group Publishing Limited 1469-1930. 
Peraturan Daerah Khusus Provinsi Papua No 1. 2007. Pembagian dan Pengelolaan Penerimaan Dalam Rangka Pelaksanaan Otonomi Khusus. Jayapura, Indonesia.

Paraturan Daerah Nomor 5. 2006. Pembangunan pendidikan di Provinsi Papua. Tentang Otonomi Khusus Bagi Provinsi Papua. Pemerintah Provinsi Papua, Undang-undang RI, Nomor 21. 2001.

Pekman, J. 1998. Capital district health authority research ethics board. In McDonald q.v. (see also D. Zussman) (1999), Proposed Governance Structure for the Canadian Institutes of Health Research. Ottawa: Public Policy Forum (Version 2.11 August 28th, 2003). http:/ /www.governance.uottawa.ca/english/ overview/o_defi.htm (accessed August 25th, 2003).

Penrose. 1959. Examining the Penrose effect in an international business context: The dynamics of Japanese firm growth in U.S. industries. Brookings Papers on Economic Activity (1987). www.business.uiuc.edu/ Working_Papers/papers/03"0113.pdf

Sedarmayanti. 2003. Tata Kearsipan dengan Memanfaatkan Teknologi Modern: 64. Bandung. Mandar Maju.

Supoyo, M. 2006. Studi sistem monitoring dan evaluasi dalam rangka disentralisasi pada Departemen Dalam Negeri Republik Indonesia. Disertasi. PDIM FE Universitas Brawijaya, Malang, Indonesia.

Teece. 1998. Capturing value from knowledge assets: the new economy, markets for know-how, and intangible assets. California Management Review 40 (3): 55-79.

Weber, M.1960. Sekte-sekte Protestan dan semangat kapitalisme. T. Abdullah (ed.), Agama, Etos Kerja dan Perkembangan Ekonomi (1979). Jakarta, Indonesia: LP3ES.

Wernerfelt. 1984. A resource-based view of the firm. Strategic Management Journal 5 (2): 171-80.

Zaheer, A., and N. Venkatraman. 1995. Relational governance as an interorganizational strategy: an empirical test of the role of trust in economic exchange. Strategic Management Journal 16 (5): 373-92. 
